\title{
Analyzing The Risk Thresholds For Banning Political Parties After NPD ॥|
}

\author{
James $\operatorname{Hogan}^{1}$ \\ Melbourne, Australia \\ Corresponding author: jfhogan@protonmail.ch
}

(Received 19 November 2020; accepted 13 April 2021)

\begin{abstract}
The recent global growth of anti-democratic sentiment has renewed the question of when a political party should be barred from the electoral arena. In modern democracies, even explicitly militant ones, constitutional mechanisms for banning political parties are rarely used. The recent decision by the German Federal Constitutional Court (BVerfG) not to ban the National Democratic Party, despite its neo-Nazi platform, is an example of this restraint, with the BVerfG introducing a new, stricter criterion called "potentiality" for the dissolution of a political party under the German Basic Law. This article draws on neo-institutionalism and comparative constitutional law to explore the democratic ramifications of three different European thresholds for banning an anti-democratic political party: the presumptive test previously used by the BVerfG, the new potentiality criterion introduced by the BVerfG, and the European Court of Human Rights' requirement for the party in question to be an imminent threat before it can be dissolved.
\end{abstract}

Keywords: The National Democratic Party; political parties; political exclusion; militant democracy; neo-institutionalism; institutional design; the European Convention on Human Rights

\section{A. Introduction}

On January 17, 2017, the German Federal Constitutional Court (BVerfG) rejected the latest application by Germany's sixteen states to ban the National Democratic Party (NPD). ${ }^{2}$ The case was brought under Article 21(2) of the German Basic Law, which renders parties that "seek to undermine or abolish the free democratic basic order" unconstitutional. ${ }^{3}$ While the BVerfG agreed that

\footnotetext{
${ }^{1}$ BSc, JD (University of Melbourne). I thank Professor Joo-Cheong Tham of the University of Melbourne and Campbell MacGillivray of the University of Göttingen for their comments on earlier drafts of this article. I also thank the editorial staff of the German Law Journal and the student editing team at the Washington and Lee University School of Law for reviewing, finalizing and publishing this article. This article was first drafted in February 2019 and was submitted to the German Law Journal for publication in November 2020. The argument has been kept as it was at the time of that submission. All errors are my own.

${ }^{2}$ Bundesverfassungsgericht [BVerfG] [Federal Constitutional Court of Germany], 2 BvB 1/13, (Jan. 17, 2017), (Bundesverfassungsgericht trans.) [hereinafter NPD II]. See also Press Release, Bundesverfassungsgericht, No prohibition of the National Democratic Party of Germany as there are no indications that it will succeed in achieving its anti-constitutional aims, Press Release No. 4/2017 (Jan. 17, 2017), https://www.bundesverfassungsgericht.de/SharedDocs/Pressemitteilungen/ EN/2017/bvg17-004.html.

${ }^{3}$ Grundgesetz [GG] [Basic Law], Article 21(2) (Christian Tomuschat, Professor David Currie, Professor Donald Kommers and Raymond Kerr, in cooperation with the Language Service of the German Bundestag, trans.), translation at https://www. gesetze-im-internet.de/ [hereinafter German Basic Law].
}

(C) The Author(s) 2022. Published by Cambridge University Press on behalf of the German Law Journal. This is an Open Access article, distributed under the terms of the Creative Commons Attribution licence (https://creativecommons.org/licenses/by/4.0/), which permits unrestricted re-use, distribution, and reproduction in any medium, provided the original work is properly cited. 
the NPD's political aims were "anti-constitutional," 4 it departed from its earlier interpretation of the word "seek." Previously, the term would be satisfied if the party in question sought to enact a substantively anti-democratic ideology. ${ }^{6}$ Here, the BVerfG re-interpreted it to include a criterion of "potentiality," which requires there to be specific and weighty indicators that suggest the party could achieve its anti-democratic goals. ${ }^{7}$ In this instance, those indicators were absent.

The BVerfG's judgment arrived during a flurry of academic interest in the political exclusion of anti-democrats, ${ }^{8}$ in part inspired by the recent resurgence of populism. ${ }^{9}$ Currently, it is largely accepted in Europe that the prohibition of a political party is justified to protect democracy in exceptional circumstances. ${ }^{10}$ This is reflected by the standard for political exclusion under Article 11(2) of the European Convention on Human Rights (ECHR), which requires the party in question to be an imminent threat. ${ }^{11}$ However, potentiality is a lower threshold than the ECHR's standard. As such, the decision in NPD II is an opportunity to examine the democratic value of three different legal criteria-the BVerfG's prior presumptive approach, the BVerfG's new potentiality approach, and the imminent threat test of the European Court of Human Rights (ECtHR) - for the prohibition of anti-democratic political parties. While comparative constitutional lawyers have produced descriptive accounts of how European states exclude anti-democrats, ${ }^{12}$ the normative value of these three thresholds has not been fully explored. ${ }^{13}$

However, an analysis of these thresholds cannot ignore the institutional environments in which they are deployed. ${ }^{14}$ This article draws on comparative constitutional law and neo-institutionalism to examine the possible effects of these three prohibition criteria, using NPD II as a primary case study and specifically focusing on the impact of institutional design. To establish a base case,

\footnotetext{
${ }^{4} N P D I I$ at para. 846 .

${ }^{5} \mathrm{Id}$. at paras. $571-627$.

${ }^{6}$ See Bundesverfassungsgericht [BVerfG] [Federal Constitutional Court of Germany], 2 BVerfGE 1, (Oct. 23, 1952) (Donald
} Kommers, trans.) [hereinafter the SRP Case] and Bundesverfassungsgericht [BVerfG] [Federal Constitutional Court of Germany], 5 BVerfGE 85, (Aug. 17, 1956), (Donald Kommers, trans.) in Donald Kommers, The Constitutional Jurisprudence of the Federal Republic of Germany 223-29 (Donald Kommers \& Russel Miller eds., 3rd ed. 1989) [hereinafter the KDP Case].

${ }^{7} \mathrm{NPD} I I$ at paras. $585-86$.

${ }^{8}$ See, e.g., Giovanni Capoccia, Militant Democracy: The Institutional Basis of Democratic Self-Preservation, 9 ANN. REV. L. \& Soc. Sci. 207 (2013); Militant Democracy - Political Science, Law and Philosophy (Afshin Ellian \& Bastiaan Rijpkema eds., 2018); Samuel Issacharoff, Fragile Democracies: Contested Power IN THE ERA Of Constitutional CourTs (2018); Carlo Invernizzi Accetti \& Ian Zuckerman, What's Wrong with Militant Democracy?, 65(15) POL. STUD. 182 (2017).

${ }^{9}$ See, e.g., Tom Ginsburg, Aziz Huq, \& Mila Versteeg, The Coming Demise of Liberal Constitutionalism?, 85 U. CHI. L. REV. 239 (2018). See also Samuel Issacharoff, Democracy's Deficits, 85 U. CHI. L. Rev. 485 (2018), and Jan-Werner Müller, Militant Democracy and Constitutional Identity in Comparative Constitutional Theory 421 (Gary Jacobsohn \& Miguel Schor eds., 2018). While populism is not necessarily anti-democratic, it is often illiberal, and is therefore discussed as a target of political exclusion even in cases where the party may not seek to overthrow democracy itself. See Ellian \& Rijpkema, Introduction in Ellian \& Rijpkema eds., supra note 7, at 4 (citing Cas Mudde \& Cristóbal Rovira Kaltwasser, Populism: A Very SHORT InTroduction 108-09 (2017)). However, it should be noted that "populism" is an ideologically flattening term, to borrow a phrase from Adam H. Johnson, previously of Fairness \& Accuracy in Reporting. Its semantic content often depends on the perspective and political motivations of the author. While this article uses the term to remain consistent with the recent literature — and with the current operation of militant democracy more generally-any discussion of "populism" should be done with an awareness of how the term is being deployed.

${ }^{10}$ See European Commission for Democracy Through Law, Guidelines on Prohibition and Dissolution of Political Parties and Analogous Measures (2000), https://www.venice.coe.int/webforms/documents/default.aspx?pdffile=CDL-INF(2000)001-e [hereinafter Venice Guidelines]. See also Ellian \& Rijpkema eds., supra note 7.

${ }^{11}$ Refah Partisi (the Welfare Party) v. Turkey, 2003-II Eur. Ct. H.R. at paras. 102-03 [hereinafter Refah].

${ }^{12}$ Capoccia, supra note 7 , at 208.

${ }^{13} I d$. at $215-19$.

${ }^{14}$ Samuel Issacharoff, Pamela S. Karlan, \& Richard H. Pildes, The LaW of Democracy: Legal Structure of the Political Process 1-13 (4th ed. 2012). See also James G. March \& Johan P. Olsen, The Logic Of Appropriateness IN The Oxford Handbook of Political Science 480 (Robert E Goodin ed., 2011); Ran Hirschl, From Comparative Constitutional Law to Comparative Constitutional Studies 11 INT. J. Const. L. 1 (2013). 
it first assumes that the political exclusion of anti-democrats, if done in accordance with the standards of the ECHR, is justifiable. ${ }^{15}$ It then argues that the replacement of the presumptive approach in Germany with potentiality is defensible, if not necessarily ideal, for two reasons. First, it is more democratic than the prior, purely substantive test of the BVerfG, as it avoids the arbitrariness of denying political participation to organizations that are not a threat. Second, in the German context, potentiality imposes greater institutional pressure on anti-democratic parties without causing an excessive increase in democratic impairment.

The second limb of this argument explores an overlooked source of risk for political exclusion. The threat of anti-democratic forces securing a political majority and the danger of democratic backlash — that is, the negative effects of banning the party being worse than letting it persist - are often discussed in the context of militant democracy. ${ }^{16}$ However, the possibility of majoritarian interests influencing the use of the exclusion mechanism for political purposes is relatively ignored. This risk is an argument against using the potentiality criterion, as its more speculative nature provides greater scope for abuse. However, the German constitution has a narrowly tailored mechanism for banning political parties when compared to other European states. Further, the institutional structure and identity of the German judiciary is particularly insulated from political pressure. As such, the risk of the banning mechanism being re-appropriated is reduced in Germany, justifying, in part, the use of potentiality as the standard. In states with broader exclusion norms or less insulated courts, the ECtHR's approach is safer, as it reduces the scope for these banning mechanisms to be misused. Naturally, the ECtHR's approach reduces the court's ability to resist anti-democratic forces. However, the defense of democracy should not be entirely exported to the judiciary. Protecting democracy requires more than an effective court. It also depends on economic, social, and political conditions that minimize anti-democratic sentiment. Political exclusion is not a complete cure. It is, at best, an effective last resort.

Part B outlines the comparative and neo-institutional methodologies used in this analysis. Part $\mathrm{C}$ outlines the concept of prohibiting anti-democratic political parties. Part D explores the potentiality criterion in depth, comparing it to both Germany's prior test and the current approach of the ECtHR. Part E briefly comments on how political exclusion should be employed alongside other mechanisms for protecting democracy.

\section{B. Methodology}

This article employs a functionalist approach to comparative constitutional analysis to explore how effectively the three criteria advance democracy. ${ }^{17}$ The focus is heavily normative, with the article seeking to identify which mechanism produces democratically ideal consequences. Legally, the key variables are how the prohibitions are formulated and how political parties are regulated in the given state. The key elements of democracy discussed by this article will be democratic responsiveness, ${ }^{18}$ the right to political participation, ${ }^{19}$ and the preservation and

\footnotetext{
${ }^{15}$ Some authors argue that the political exclusion of anti-democratic parties can never be justified on philosophical grounds, for an example, see Accetti \& Zuckerman, supra note 7, at 7. A full discussion of whether militant democracy is normatively permissible in the first place is beyond the scope of this article.

${ }^{16}$ Gelijn Molier \& Bastiaan Rijpkema, Germany's New Militant Democracy Regime: National Democratic Party II and the German Federal Constitutional Court's 'Potentiality' Criterion for Party Bans, 14 Eur. Const. L. Rev. 394, 399 (2018).

${ }^{17}$ See Vicki C. Jackson, Comparative Constitutional Law: Methodologies in The Oxford Handbook of Comparative Constitutional Law 54, 62-66 (Michel Rosenfeld \& András Sajó eds., 2012).

${ }^{18}$ Democratic responsiveness - the ability of a democratic government to respond to the preferences of its constituents-is generally considered to be a central characteristic of responsible and representative government.

${ }^{19}$ The interpretation of this concept, for the purposes of this article, is based on the assumption that political parties are the primary vehicle for political participation.
} 
advancement of human dignity. ${ }^{20}$ This article assumes that maximizing these elements is valuable. $^{21}$

However, constitutions "neither originate nor operate in a vacuum."22 First, the operation of a constitutional system is dependent on the broader social and political forces of its environment. ${ }^{23}$ Second, by creating, limiting, and allocating power, constitutions entrench particular norms and institutional structures. ${ }^{24}$ Accordingly, when adopting this functionalist approach to explore how different constitutional systems address a common problem, it is valuable to account for how the institutional environment shapes - and is shaped by — the law. This is particularly relevant when conducting detailed case studies rather than relying on large- $\mathrm{N}$ sampling, as the use of the smaller sample size increases the influence of these confounding variables on the analysis. ${ }^{25}$

To account for the effects of these social and political contexts, this article draws on aspects of neo-institutionalism. ${ }^{26}$ Neo-institutionalism incorporates the cognitive elements of behavioralism and rational choice theory into institutional analysis. ${ }^{27}$ Within this framework, institutionsdefined as "relatively enduring collection[s] of rules and organized practices" 28 — not only enable and constrain political actors, ${ }^{29}$ but also construct politics by framing the goals that these actors believe they can pursue. ${ }^{30}$ Naturally, these constructions and constraints are not necessarily deterministic, especially because the interdependence of institutions, cultural norms, and political experiences becomes increasingly complex in larger systems. ${ }^{31}$ Ultimately, behavior is driven by a combination of "habit, emotion, coercion, and calculated expected utility, as well as [the] interpretation of internalized rules and principles." 32 Nonetheless, these constraints provide a context for action, ${ }^{33}$ creating a bias in behavior and shaping political activity. ${ }^{34}$

This approach has two distinct advantages for the research question. First, the question of party prohibition is firmly entrenched in the political domain. ${ }^{35}$ While constitutional courts are often idealized as independent and impartial, ${ }^{36}$ their decision-making can be susceptible to political influences. ${ }^{37}$ One possible influence is the threat of political actors curbing the court by limiting its jurisdiction or packing it with allies. ${ }^{38}$ The degree to which this is possible depends on the

\footnotetext{
${ }^{20}$ Conceptions of democracy vary. The European context of this research question renders substantive conceptions of democracy - as opposed to procedural or formal conceptions-particularly relevant.

${ }^{21}$ The philosophical value of democracy is assumed.

${ }^{22}$ Hirschl, supra note 14 , at 2.

${ }^{23}$ Hirschl, supra note 14 , at 2. See also Ran Hirschl, Comparative Matters: The Renaissance of Comparative CONSTITUTIONAL LAW (2014).

${ }^{24}$ Hirschl, supra note 14 , at 2-3.

${ }^{25}$ Jackson, supra note 17 , at 64-65.

${ }^{26}$ The terms "new institutionalism" and "neo-institutionalism" are used interchangeably in academic literature. This article uses "neo-institutionalism" for consistency.

${ }^{27}$ André Lecours, New Institutionalism: Issues and Questions in New InSTITUTIONALism: TheORY AND ANALYsis 3-22 (André Lecours ed., 2005).

${ }^{28}$ James G. March \& Johan P. Olsen, Elaborating the "New Institutionalism" in Goodin ed., supra note 14, at 159. These collections of rules and practices include governmental and constitutional bodies, such as the executive, the legislature, and the various organs of the judiciary. Political parties are also generally regarded as institutions. See, e.g., JOHN H ALDRICH, Political Parties In and Out of Legislatures, in Goodin ed., supra note 14.

${ }^{29}$ March \& Olsen, supra note 28 , at 160.

${ }^{30}$ Hirschl, supra note 14, at 2, citing Mark Tushnet, Why The Constitution MatTers (2012).

${ }^{31}$ March \& Olsen, supra note 28, at 164.

${ }^{32}$ March \& Olsen, supra note 14 , at 490.

${ }^{33}$ Lecours, supra note 27 , at 10 .

${ }^{34} I d$. at 9. See also March \& Olsen, supra note 28, at 164.

${ }^{35}$ See, e.g., Accetti \& Zuckerman, supra note 7. See also Issacharoff et al., supra note 14.

${ }^{36}$ Aharon Barak, The Judge IN A DEMOcracy 20-23 (2006).

${ }^{37}$ Dave Bridge, The Supreme Court, Factions, and the Counter-Majoritarian Difficulty, 47(4) PoliTy 420, 423 (2015), citing Martin Shapiro, Political Jurisprudence, 52 Ky. L. J. 294 (1964). See also Justin Crowe, Building THE JudiCiary 5 (1st ed. 2012).

${ }^{38}$ Tom S. Clark, The Separation of Powers, Court Curbing, and Judicial Legitimacy, 53 AM. J. PoL. SCI. 971, 972 (2009).
} 
institutional environment. Another is the danger of the court exhausting its supply of "diffuse support." 39 This term, coined by David Easton, ${ }^{40}$ refers to the "reservoir of favorable attitudes or good will" towards the institution that allows "members to accept or tolerate outputs to which they are opposed." ${ }^{41}$ A loss of this support reduces a court's ability to make counter-majoritarian decisions without suffering popular rebuke. ${ }^{42}$ These considerations are consistent with research showing that courts strategically alter their behavior in response to their broader political environment, ${ }^{43}$ with constitutional courts often employing measures to avoid direct conflict with political branches. ${ }^{44}$ The result of these factors is that the decisions of constitutional courts often have a majoritarian bias. ${ }^{45}$ When assessing the function of constitutional mechanisms, this can be crucial, as it affects how the norms operate in practice.

Second, the threat of political exclusion is a unique form of institutional pressure. In representative democracies, the party provides a vehicle for participation and political legitimacy. ${ }^{46}$ However, the creation and advancement of a political party requires time, energy, and capital. A party ban aims "to deny extremist parties the forum of institutional expression, the legitimacy, and the aura of respectability that is naturally granted to political parties in modern democracy." 7 Consequently, the value of using the party model must be assessed against the risk of having that party banned and losing that source of legitimacy. ${ }^{48}$ Neo-institutionalism provides insight into how political actors respond to such risks. Moreover, it details how actors respond to the existence of "veto players," which are entities whose approval is required for certain outcomes. ${ }^{49}$ Crucially, decision makers tend to be risk averse in conditions of systemic uncertainty.$^{50}$ Further, individuals and organizations do not assess risk in a purely rational fashion. ${ }^{51}$ Systemic biases are noted factors in governmental and individual behavior. ${ }^{52}$ The consequence of these behavioral trends is that certain institutional conditions can amplify the effect of certain norms, which in turn can increase the effective impairment of these norms on the rights of particular actors.

As such, the analysis of the legal variables - the text and interpretation of the different prohibition mechanisms, combined with the broader constitutional protections afforded to political parties - will be supplemented by data relating to the influence of institutions on both the judiciary and political parties. To limit the scope of this article, the potential influence of cultural attitudes towards anti-democratic parties, as distinct from institutional and legal factors,

\footnotetext{
${ }^{39}$ Adam S. Chilton \& Mila Versteeg, Courts' Limited Ability to Protect Constitutional Rights, 85 U. CHI. L. REv. 293,301 (2018).

${ }^{40} I d$.

${ }^{41} I d$. (citing David Easton, A Systems Analysis of Political Life 273 (1979)).

${ }^{42} I d$.

${ }^{43}$ See, e.g., Tom S. Clark, The Limits of Judicial IndePendence (2011). See also Bridge, supra note 36, and Aylin Aydin, Judicial Independence Across Democratic Regimes: Understanding the Varying Impact of Political Competition, 47 L. \& SoC. REV. 105 (2013).

${ }^{44}$ Rosalind Dixon \& Samuel Issacharoff, Living to Fight Another Day: Judicial Deferral in Defense of Democracy, WIS. L. REV. 683, 699 (2016). This exploration of deferral techniques includes an examination of German courts.

${ }^{45}$ Chilton \& Versteeg, supra note 38 , at 320.

${ }^{46}$ Anika Gauja, Political Parties and Elections: Legislating for Representative Democracy 1-4 (2010).

${ }^{47}$ Gur Bligh, Defending Democracy: A New Understanding of the Party-Banning Phenomenon 46 Vand. J. Transnat'L L. 1321, 1365 (2013).

${ }^{48}$ For an elaboration on this concept of legitimacy as capital in neo-institutionalism, see David Béland, Ideas, Interests, and Institutions: Historical Institutionalism Revisited, in Lecours ed., supra note 27, at 39.

${ }^{49}$ Lecours, supra note 27 , at 10 . Constitutional courts are an example of a veto player in this context.

${ }^{50} \mathrm{Hirschl}$, supra note 14 , at 5 , noting that this fact has value for the study of comparative constitutional law.

${ }^{51}$ W. Kip Viscusi, How Do Judges Think About Risk?, 1(1/2) AM. L. \& Econ. Rev. 26, 26-29 (1999).

${ }^{52} I d$.
} 
will not be discussed. ${ }^{53}$ Further, the article assumes that the primary political goal of anti-democratic parties can be generalized as the accrual of power and legitimacy. ${ }^{54}$ Lastly, the conclusions of this article are not deterministic. The methodology is based on biases, risks, and socio-political trends. While this approach is appropriate for exploring the value of norms that manage democratic risks, it cannot be treated as absolute, especially because this article draws on trends from several jurisdictions.

Comparisons are made throughout the article to other European democracies, with a primary focus on the Netherlands. Where these comparisons are made, the comparative cases are representative democracies that are also signatories to the ECHR.

\section{Prohibiting Parties to Protect Democracy}

The possibility of anti-democrats abusing democratic institutions to gain power is often described as the "paradox of democracy." ${ }^{5}$ Today, few states have adopted Hans Kelsen's model of a tolerant, procedural democracy that allows anti-democrats to achieve power. ${ }^{56}$ Instead, they employ measures to suppress organizations that seek to undermine them, with preventive party prohibitions being one such mechanism. ${ }^{57}$ When the concept was first proposed by Karl Loewenstein, it was justified as a means of protecting liberal democracy from fascism. ${ }^{58}$ Since Loewenstein's original thesis in 1937, party prohibitions have also been defended as state interventions in failing political markets, ${ }^{59}$ preventive measures to protect civil rights, ${ }^{60}$ and mechanisms for preserving political pluralism. ${ }^{61}$ Further, the doctrine has expanded from the original focus on preventing anti-democrats from taking power to include bans on parties that incite hate and discrimination, parties that support violence or terrorism, and parties that attack the constitutional identity of the state. ${ }^{62}$ Since 1945 , nineteen European states have banned political parties on these bases. ${ }^{63}$

However, political parties provide a forum for popular representation, ${ }^{64}$ and are essential to our current forms of representative democracy. ${ }^{65}$ Accordingly, the prohibition of a party represents a

\footnotetext{
${ }^{53}$ Example cultural factors include public opinion-outside the exercise of democratic powers-and representations provided by media, journalistic or otherwise. The "culture" of a court, as a legal and institutional question, is distinguished from broader conceptions of culture for the purposes of this article, as the culture of the court is an intrinsic component of how it operates as a judicial entity.

${ }^{54}$ Lecours, supra note 27 , at 11 . The primary purpose of a political party is to acquire public representation, with all the legitimacy that it provides. Other secondary purposes could be grounded in emotional or behavioral drives, such as a desire to be democratically vindicated.

${ }^{55}$ Gregory Fox \& Georg Nolte, Intolerant Democracies, 36 Harv. InTL. L. J. 1, 14 (1995). See also Müller, supra note 8 , at 418 .

${ }^{56}$ Günter Frankenberg, Democracy, in Rosenfeld \& Sajó eds., supra note 16, at 259-60.

${ }^{57}$ Other examples include limiting speech and defunding certain political parties.

${ }^{58}$ See Karl Loewenstein, Militant Democracy and Fundamental Rights, I, 31(3) Am. Pol. SCI. Rev. 417 (1937); Karl Loewenstein, Militant Democracy and Fundamental Rights, II, 31(4) AM. PoL. SCI. ReV. 638 (1937).

${ }^{59}$ See, e.g., Samuel Issacharoff, Fragile Democracies, 120 Harv. L. Rev. 1407, 1414 (2007).

${ }^{60}$ Paul Cliteur \& Bastiaan Rijpkema, The Foundations of Militant Democracy, in The STAte of ExcePtion AND Militant Democracy in a Time of Terror 265-66 (Afshin Ellian \& Gelijn Molier eds., 2012).

${ }^{61}$ See, e.g., Gelijn Molier, Justifying Militant Democracy: Philosophical and Legal Reflections on Dutch Militant Democracy, in Ellian \& Rijpkema eds., supra note 7, at 99-105. See also Alexander S Kirshner, A TheORY of MilitANT DemOCRACY: The Ethics of Combatting Political Extremism 123 (2014); Issacharoff, supra note 59, at 1463-66.

${ }^{62} \mathrm{Bligh}$, supra note 47 . Comparative studies have found that the party's use of violence is a particularly prominent basis, see Nancy L. Rosenblum, Multiculturalism and the Anti-Discrimination Principle, 1 L. \& ETHICs Hum. RTs. 1 (2007).

${ }^{63}$ Angela K. Bourne, Militant Democracy and the Banning of Political Parties in Democratic States: Why Some Do and Why Some Don't, in Ellian \& Rijpkema eds., supra note 7, at 25.

${ }^{64}$ Cindy Skach, Political Parties and the Constitution, in Rosenfeld \& Sajó eds., supra note 16, at 875. See also Aldrich, supra note 28 , at 198 .

${ }^{65}$ Gauja, supra note 46 , at 182.
} 
restriction on the boundaries of democratic participation. Consequently, it is widely agreed that this mechanism is an exceptional measure that should only be employed in limited circumstances. The prevailing test in Europe requires there to be "sufficient evidence that there is a real threat to the constitutional order or citizens' fundamental rights and freedoms." ${ }^{\prime 6}$ Courts are generally regarded as the appropriate institution to exercise this power. ${ }^{67}$

The problematic element is the preventive nature of these bans. They are not a penalty for proscribed conduct. Instead, they dissolve the party before it can achieve its political goals. In this respect, these bans are a form of "constitutional risk aversion." ${ }^{8}$ In some states, the risk will be presumed due to the ideology of the party. ${ }^{69}$ In others, more evidence relating to the structure, behavior, and political attitudes of the party is required to support the ban. ${ }^{70}$ In the latter case, the ban is typically justified by reference to how the party in question threatens a particular object, such as democracy, ${ }^{71}$ public order ${ }^{72}$ or human dignity. ${ }^{73}$ Organizations that are a presumed, potential, or imminent threat to that object may be dissolved. ${ }^{74}$ Crucially, the timing of this ban needs to be balanced against the rights of its members to association and representation.

Most European states employ the latter approach. ${ }^{75}$ Under this approach, because the exclusion mechanism is conceptualized by reference to some protected object, the scope of what can be banned is limited only by the semantic boundaries of that object and the degree of threat required. A tightly constructed object, given clear content by case law and judicial commentary, creates a far narrower prohibition mechanism than a broad, ill-defined one. Equally, the degree of threat will affect the potential scope of prohibition. A high threshold will be enlivened only in exceptional circumstances, whereas a low threshold is far more flexible. Accordingly, it is crucial to define clearly both the protected object and the degree of threat required. A failure to do so creates the risk of the prohibition mechanism having too broad an effect. This in turn could impair legitimate democratic rights more than is necessary.

A key element of these norms is their uniqueness as a regulatory mechanism. Legal norms typically regulate behavior by punishing certain conduct or enforcing existing arrangements. In these respects, they operate relatively predictably. However, the constitutional norms used to prohibit parties, when they are predicated on a degree of threat, introduce an additional degree of uncertainty. Because the idea of threat requires a prospective assessment of whether a particular outcome is possible, founded on a mass of variables and confounding factors, the point at which the party will qualify as a threat to the protected object is difficult to predict. Consequently, an anti-democratic party cannot know exactly when it may be within the scope of prohibition. It can only make assumptions about when it will achieve the threshold influence or ability to justify a ban. As such, navigating a political environment with these prohibition mechanisms also becomes a question of risk assessment on its behalf.

\footnotetext{
${ }^{66}$ Venice Guidelines, supra note 9.

${ }^{67} \mathrm{Id}$. See also Müller, supra note 8 , at 421.

${ }^{68}$ András Sajó, Militant Democracy 213 (2004). It should be noted that, while party prohibitions are generally framed as constitutional protections, the Netherlands relies on its civil code for political exclusion.

${ }^{69}$ See, e.g., Constitution of The Republic of Poland Apr. 2, 1997, art. 13. See also Issacharoff, supra note 59, at 1414.

${ }^{70} \mathrm{See}$, e.g., Refah.

${ }^{71}$ See, e.g., TÜrkiYe CUMHURIYeti ANAYASASI art. 68 (Turkish Constitution); Grundgesetz [GG] [Basic Law] art. 21, and CONSTITUCIÓN ESPAñola art. 6 (Spain)

${ }^{72}$ See, e.g., CONSTitution of The Republic of Poland Apr. 2, 1997, art. 13, and ÚSTAVA SLOVENSKEJ REPUBLIKY [Constitution] art. 29 (Slovk.).

${ }^{73}$ See, e.g., Turkish Constitution art. 68.

${ }^{74}$ Molier, supra note 61, at 113.

${ }^{75}$ Article 13 of the Polish Constitution is a counter-example. It bans political parties "whose programmes are based upon totalitarian methods and the modes of activity of Nazism, fascism and communism". This excludes certain political parties based on their behavior rather than on the threat they pose to a particular object-at least explicitly.
} 


\section{NPD // and Potentiality}

This section contextualizes the various criteria for political exclusion before providing a critical analysis of the introduction of potentiality in Germany. First, the introduction of a threat criterion avoids the arbitrariness of the BVerfG's prior approach. It also allows anti-democrats to remain within the electoral process, providing some scope for their behavior to be moderated through acculturative pressure. Second, the use of potentiality instead of imminence as the threat criterion is justifiable, as the greater pressure that potentiality imposes on anti-democratic behavior is commensurate to the greater impairment it has on democratic responsiveness. This second point relies on how Germany's institutional structure mitigates the dangers of potentiality.

\section{Context: Potentiality, Threat, and the BVerfG}

1. The German Basic Law and the Previous Test of the BVerfG

Under Article 21(1) of the German Basic Law, political parties are recognized as "necessary factors of life under the constitution" and granted special protection. ${ }^{76}$ They can only be banned by the BVerfG under Article 21(2), which reads: ${ }^{77}$

Parties that, due to their aims or the behavior of their adherents, seek to undermine or abolish the free democratic basic order or to endanger the existence of the Federal Republic of Germany shall be unconstitutional.

The protected objects in this case - the "free democratic basic order" and the German state-are given content by Article 20 of the Basic Law and the jurisprudence of the BVerfG. The three most crucial elements of this concept, according to the modern BVerfG, are the guarantee of human dignity, the rule of democracy, and the Rechtsstaat principle. $^{78}$

The first case employing this mechanism - the banning of the Socialist Reich Party (SRP) in 1952 - clarified the content of this standard. A party will not be declared unconstitutional simply because it seeks to reform particular constitutional provisions or institutions. ${ }^{79}$ Only parties that seek to undermine the foundations of the democratic basic order are at risk of dissolution. ${ }^{80}$ The SRP Case gave little insight into the full scope of Article 21(2), as it was resolved primarily on the similarities between the SRP and the Nazi Party. ${ }^{81}$ However, it did highlight the democratic implications of rendering a party unconstitutional. As Currie notes, dissolving the SRP based on the behavior of its members invoked senses of guilt by association and highlighted "the difficulty of distinguishing subversive rhetoric from legitimate political oratory." 82

The decision to ban the Communist Party of Germany (KPD) in 1956 provided a more complete explanation of the conditions for political exclusion under Article 21(2). First, it clarified that violence or other criminal activity was not necessary to justify the ban. ${ }^{83}$ Further, the party did

\footnotetext{
${ }^{76}$ Lasse Schuldt, Mixed Signals of Europeanization: Revisiting the NPD Decision in Light of the European Court of Human Rights' Jurisprudence, 19 German L. J. 817, 819 (2018); Svetlana Tyulkina, Militant Democracy: Undemocratic Political Parties AND Beyond 69 (2015).

${ }^{77}$ GRUNDGESETZ [GG] [Constitution] art. 21(2).

${ }^{78}$ NPD II at paras. 538-47; Schuldt, supra note 76, at 824. For a more expansive list, the SRP Case at 13 cites the components of the free democratic basic order as including "the rights of life and the free development of the personality; popular sovereignty; separation of powers; the responsibility of the government; the lawfulness of administration; the independence of the courts; and the plurality and equality of political parties with a right to constitutional development and the exercise of political opposition". See Justin Collings, Democracy's Guardians: A History of the German Federal Constitutional Court 1951-200139 (2015).

${ }^{79}$ David Currie, The Constitution of the Federal Republic of Germany 216 (1994), citing the SRP Case at 12-13.

${ }^{80} I d$. (citing the SRP Case at 12-13).

${ }^{81} I d$.

${ }^{82} \mathrm{Id}$. at 217.

${ }^{83} I d$. at $220-21$.
} 
not have to pose a danger to Germany's democracy. ${ }^{84}$ All that was required for a party to be unconstitutional was a concrete intention to enact political aims that opposed the free democratic basic order of Germany. ${ }^{85}$ Notably, this is not a proscription on ideas. ${ }^{86}$ "Merely advocating the overthrow of the government" is insufficient. ${ }^{87}$ The anti-democratic ideas have to be translated into a "political program." 88 Crucially, the party will be unconstitutional even if it had "no prospect of achieving its unconstitutional aims in the near future." 89

In this respect, prior to NPD II, the BVerfG interpreted the underlying norm narrowly, limiting its application to parties that sought to undermine the Basic Order. This relied on a single dimension of analysis: the substantive policies and behavior of the party. No further analysis of threat was conducted.

\section{2. "Imminent Threat" and the ECtHR}

While no provision of the ECHR explicitly regulates the rights of political parties, these organizations can rely on the freedom of association under Article 11, providing them an avenue of appeal against party prohibitions. ${ }^{90}$ Article 11(2) of the ECHR provides that "no restrictions" are to be imposed on the freedoms of assembly and association unless they are "prescribed by law and ... necessary in a democratic society." While the meaning of "democracy" for the purposes of Article 11(2) does not have a closed definition, ${ }^{92}$ the preamble to the Statute of the Council of Europe cites "the spiritual and moral values which are common heritage of their peoples and the true source of individual freedom, political liberty and the rule of law" as "principles which form the basis of all genuine democracy." ${ }^{93}$ Consequently, the definitions used by the ECtHR and the BVerfG are similar.

The case of Refah made it clear that the "dissolution of an entire political party" is allowed "only in the most serious cases" where there is "plausible evidence that the risk to democracy, supposing it [has] been proved to exist, [is] sufficiently imminent." 94 The ECtHR affords only a limited margin of appreciation to its Member States in complying with Article 11(2). ${ }^{95}$ This margin of appreciation acknowledges that "the historical context and constitutional specifics of a country have to be taken into account" when assessing whether a domestic prohibition mechanism is compliant with the ECHR. ${ }^{96}$

The facts of Refah contextualize what qualifies as an imminent threat. In that case, the Welfare Party had secured 22 percent of the vote in the general election, 35 percent in local elections, and held 158 seats in the national parliament. ${ }^{97}$ It was the largest party in Turkey and, based on an opinion poll cited by the ECtHR, it could have secured 67 percent of the vote in the next general

\footnotetext{
${ }^{84} I d$.

${ }^{85}$ Kommers, supra note 6, at 228.

${ }^{86}$ Molier \& Rijpkema, supra note 16 , at 396.

${ }^{87}$ Kommers, supra note 6, at 228.

${ }^{88}$ Molier \& Rijpkema, supra note 16 , at 396.

${ }^{89}$ KPD Case (Gelijn Molier \& Bastiaan Rijpkema, trans.), in Molier \& Rijpkema, supra note 16, at 397.

${ }^{90}$ Council of Europe, Convention for the Protection of Human Rights and Fundamental Freedoms, Sept. 3, 1953,

Europ. T.S. No. 5.

${ }^{91}$ Id. at art. 11(2).

${ }^{92}$ For a discussion of the concept of democracy within the ECHR see Joseph Zand, The Concept of Democracy and the European Convention on Human Rights, 5 U. BALT. J. INTL. L. 195 (2017).

${ }^{93}$ Council of Europe, Statute of the Council of Europe, Aug. 3, 1949, Europ. T.S. 001.

${ }^{94}$ Refah at para. 104. This has been confirmed in Partidul Comunistilor v. Romania, 2005-I Eur. Ct. H.R. at para. 48, and Herri Batasuna v. Spain, 2009 Eur. Ct. H.R. at para. 83. The ECtHR's reasoning accounts for the Venice Guidelines.

${ }^{95}$ Refah at para. 46.

${ }^{96}$ Refah at paras. $105,124$.

${ }^{97}$ Schuldt, supra note 76 , at 831 .
} 
election. ${ }^{98}$ To date, the Welfare Party is the only organization that the ECtHR has considered an imminent threat to democracy due to its political influence. ${ }^{99}$

It should be stressed that Article 11(2) of the ECHR is an avenue for appealing a violation of human rights rather than a mechanism for political exclusion. Under the ECHR, a political party has the right to campaign for a change in the law if both its means of campaigning and the change itself are consistent with the law and democracy. ${ }^{100}$ The Refah threshold of imminence is the ECtHR's metric for when a party ban by a Member State will be consistent with international human rights law. ${ }^{101}$

\section{NPD //}

The ECtHR's decision in Refah was handed down in 2003, and Germany is a signatory to the ECHR. ${ }^{102}$ Accordingly, NPD II was an opportunity for the BVerfG to align its jurisprudence with the ECtHR.

Instead, it introduced potentiality. ${ }^{103}$ Under this doctrine, the party does not need to be a specific, imminent threat to democracy. ${ }^{104}$ It only needs the ability to achieve its "anti-constitutional aims." 105 If it is "entirely unlikely" that the party could achieve these aims, as determined by a holistic assessment of the political party's current circumstances, societal impact, public representation, and methods, ${ }^{106}$ then a ban is unnecessary. ${ }^{107}$ The BVerfG also stressed that this represents the complete test under Article 21(2); there are no other unwritten requirements. ${ }^{108}$

For context, at the time of the hearing, the NPD had 6,000 members, 338 local representatives, and one Member of the European Parliament. ${ }^{109}$ It had no representatives at the federal level. ${ }^{110}$ When compared to the size and influence of the Welfare Party in Refah, the NPD was far weaker, showing no signs of immediate growth or power. For this reason, despite its blatantly anti-constitutional and neo-fascist platform, it was allowed to persist under the new threat criterion of potentiality.

\section{The Value of Introducing a Threat Mechanism}

When Article 21(2) was first interpreted by the BVerfG, the substantive approach to political exclusion was justified by the Weimar experience. ${ }^{111}$ However, this reasoning needs to be understood by reference to the fragility of Germany's democracy at the time. It was a newly established system with young institutions and extant weaknesses, ${ }^{112}$ and the threat posed by anti-democratic

\footnotetext{
${ }^{98}$ Refah at para. 11.

${ }^{99}$ Schuldt, supra note 76 , at 831 . The other parties whose bans were upheld by the ECtHR in Herri Batasuna and Batasuna were found to be threats to democracy on the bases of violence and terroristic behavior rather than anti-democratic political influence.

${ }^{100} \mathrm{Id}$. at 830 .

${ }^{101}$ See, e.g., Molier \& Rijpkema, supra note 16 , at 402-03.

${ }^{102} I d$. at 400 (noting that while the German Constitution has a higher status than the ECHR in German law, the BVerfG has stated that German courts must abide by the ECHR and the ECtHR's jurisprudence unless it contradicts the Basic Law).

${ }^{103}$ NPD II at para. 585 .

${ }^{104} I d$. at para. 586.

${ }^{105} \mathrm{Id}$.

${ }^{106} I d$. at para. 587.

${ }^{107} I d$. at para. 586 .

${ }^{108} I d$. at para. 528

${ }^{109}$ Molier \& Rijpkema, supra note 16 , at 395

${ }^{110}$ Currie, supra note 79 , at $216-17$.

${ }^{111}$ See SRP Case, in Kommers, supra note 6, at 139. See also Werner Heun, The Constitution OF GeRmanY: A Contextual Analysis 96 (2011).

${ }^{112}$ Molier \& Rijpkema, supra note 16, at 398.
} 
parties was elevated by this vulnerability. Accordingly, a presumptive approach to banning certain political ideologies was more easily justified.

The problem with adopting the presumptive approach today is that, absent this post-war context, it has a disproportionate scope of application. Germany's institutions are no longer as vulnerable to the mere existence of anti-democrats. ${ }^{113}$ Consequently, the presumption that any anti-democratic party is an immediate threat simply because they exist is no longer grounded in the political reality. While it could be argued that a presumptive ban would nonetheless have normative value by signaling the appropriate boundaries of political activity, ${ }^{114}$ that purpose could equally be fulfilled by less restrictive means, such as denying the party its state subsidies. ${ }^{115}$ Ultimately, the presumption that a party is a threat solely due to its platform, without any regard to how vulnerable the protected object is to that platform, is an arbitrary boundary that fails to investigate the specific circumstances of the party in question.

The key issue is that there is no principled basis for deciding whether an ideology is sufficiently opposed to the protected object. The use of a threat mechanism can be justified in the probabilistic terms of risk aversion. However, absent any reference to risk, the decision about whether a platform is sufficiently opposed to the free democratic basic order has no clear boundary. Naturally, easy cases would exist, such as platforms that deny democracy outright. However, there are many ideological positions that impair democracy without explicitly opposing it, and do so without being directly analogous to the fascist and authoritarian movements of the twentieth century. For example, a party could support electoral policies that constructively discriminate against certain classes by stifling their ability to vote. These policies, by undermining the ability for certain members of the demos to engage politically, are arguably opposed to democracy, but they are not outright rejections of it. Alternatively, for an example of anti-democratic behavior that relates to human dignity rather than electoral access, a platform could defund public protections that, while formally available to all citizens, are particularly relied upon by certain targeted minorities, facilitating further abuses against those groups without explicitly calling for discrimination or violence. The preliminary legal question of whether these positions are opposed to the protected object would depend on how narrowly that object is defined. However, even once that question was decided, there remains the issue of deciding whether these policies-if determined to be antidemocratic - are enough to render a party supporting them anti-democratic. A party advocating for such policies would almost certainly have a platform that encompasses far more than these topics. The question of whether they are sufficiently opposed to a democratic order would need to account for how representative these policies are of the party's broader ideology.

A pragmatic determination of where the boundary of anti-democratic behavior lies in relation to these harder cases would likely need to defer to an assessment of the expected impact of the overall platform on the protected object. However, once the decision about whether a political party should be banned turns on hypothetical political outcomes, there is a latent question about whether those hypothetical outcomes would actually arise. In this sense, while an assessment of an ideology's impact may not necessarily import a threat analysis, it does naturally lead to it. ${ }^{116}$ Analyses based on historical experience would run into a similar problem. The purpose of such references is to extrapolate from past harms to justify future action, which would also import the logic of threat in the context of a hypothetical outcome. As such, to resolve hard cases,

\footnotetext{
${ }^{113} I d$.

${ }^{114}$ See Andrew K. Woods, A Behavioural Approach to Human Rights, 51 HARV. InTL. L. J. 52, 58-61 (2010). The behavioral elements discussed by Woods are not specific to human rights.

${ }^{115}$ See, e.g., GRUNDGESETZ [GG] [Constitution] art. 21(3). See also Gert-Jan Leenknegt, Militant Democracy Under a Thin Constitution: The Constitutional Position of Anti-System Parties in the Netherlands, 3 DiritTo PubBLICO Comparato Ed Europeo 713, 715-18 (2015).

${ }^{116} \mathrm{It}$ is important to distinguish between "impact" and "threat" here, as "impact" is the effect that the ideology would have on the protected object if implemented, whereas "threat" is the possibility of the political party in question securing enough power to implement that ideology.
} 
a presumptive approach either relies on an arbitrary decision about whether a platform is sufficiently similar to a proscribed ideology, which also risks being a particularly retrospective approach that may overlook newer forms of anti-democratic behavior, or it needs to import assessments of threat and impact with reference to the protected object, transforming the analysis from presumptive into something more closely resembling potentiality or imminence. Of course, a decision made under potentiality or imminence will still have a foundational degree of arbitrariness, as the definition of the protected object and the accepted threshold of threat are ultimately political constructions. However, this arbitrariness is at least tempered by the need to assess and qualify the specific risk posed by the party in question.

Notably, there may also be a practical benefit to tolerating anti-democratic parties, provided they are constrained by a threat mechanism. Individuals adopt beliefs and behavioral patterns to assimilate to their social environment. ${ }^{117}$ Nonconformity has a notable social-psychological cost, while conformity grants distinct social-psychological benefits. ${ }^{118}$ In this sense, anti-democratic parties would not be drawn into the electoral game based purely on rational incentive. They would also be drawn in by the social and institutional forces acting upon them. Naturally, social pressure is not an absolute force, and actors do not always concede ground. ${ }^{119}$ The likelihood of conformity depends on "the strength, immediacy, and size" of the group, ${ }^{120}$ with the length of exposure being a critical factor. ${ }^{121}$ Nonetheless, allowing anti-democrats access to the democratic process-especially in cases where they cannot become a majority-puts them in an environment where social pressures could possibly modulate and reform their behavior. ${ }^{122}$ This opportunity is not afforded by a purely presumptive approach.

\section{Potentiality and Imminence}

\section{The Oppressive Effects of Potentiality}

The obvious benefit of potentiality is its lower threshold for action. Under the Refah approach, anti-democratic parties retain the option of garnering enough support to render a ban politically unfeasible-a common concern among critics of the ECtHR's restrained approach. ${ }^{123}$ By comparison, potentiality allows for intervention well before this point. In doing so, it averts the risk of anti-democratic sentiment festering, reduces the threat of political backlash, ${ }^{124}$ and prevents coalitions involving the anti-democratic party from developing. ${ }^{125}$ The obvious cost to this is that it provides a lower ceiling for how large an anti-democratic political party can grow, impairing its democratic voice.

However, the use of potentiality instead of imminence is likely to have a behavioral effect on anti-democratic parties that limits them more than what would be suggested by the lower legal threshold. As discussed above, mechanisms for political exclusion, when based on a degree of threat, are more probabilistic than most other legal norms. The ECtHR's framework imposes

\footnotetext{
${ }^{117}$ Ryan Goodman \& Derek Jinks, How to Influence States: Socialization and International Human Rights Law, 54 DUKE L. J. 621, 638 (2004).

${ }^{118} I d$.

${ }^{119} \mathrm{Id}$. at 642 .

${ }^{120} I d$.

${ }^{121} I d$.

${ }^{122}$ There is a question about whether Goodman and Jinks' findings apply with the same force to political parties within a democratic system as they would to states within the international order, as parties are a coordinated, organized in-group composed of voluntary members with specific goals. In this sense, a political party will often be more unified and selfreinforcing than a state, which may allow for individuals to receive the necessary positive social-psychological feedback from within the party itself.

${ }^{123}$ Molier \& Rijpkema, supra note 16, at 399.

${ }^{124}$ Kristian Ekeli, The Political Rights of Anti-Liberal-Democratic Groups, 31(3) L. \& PHIL. 267, 291-92 (2012).

${ }^{125}$ Tyulkina, supra note 75 , at 65 . See NDP II at paras. 903, 909, noting that the NPD had no chance of securing a meaningful coalition.
} 
a threshold that requires the party to be a significant political threat. While the exact threshold for this is not quantitatively defined, an anti-democratic party can still make informed assumptions about when they may meet the threshold based on objective markers such as membership numbers and electoral results, and then settle into a position where they are too small to constitute a threat while still large enough to normalize their platform. ${ }^{126}$ By comparison, the threshold of potentiality is far less certain, as it employs a more prospective analysis. The threshold is not limited to "the most serious cases," as is the case with Refah. While potentiality still relies on a strict, objective assessment_- "specific and weighty indicators" — the test ultimately asks whether it is conceivable, given the current evidence, that the party in question could achieve its goals. This leaves far more scope for the imagination than the ECHR allows, and the greater uncertainty has a valuable behavioral effect. Because decision-makers are generally risk-averse in conditions of systemic uncertainty, the greater indeterminacy of a ban under potentiality incentivizes antidemocratic parties to remain more cautious than they may need to be, which act as a suppressant for anti-democratic growth. Notably, the scope of this phenomenon is intrinsically tied to the scope of the protected object, which is a key consideration for the design of the banning mechanism. In Germany, the idea of the "free democratic basic order," while not explicitly bounded, ${ }^{127}$ is nonetheless directly tied to the three key principles of German democracy. ${ }^{128}$ Consequently, any suppressive effect that potentiality may have is relatively targeted, especially when compared to those of some other militant democracies. ${ }^{129}$

An example of a broader object would be the one protected by the Dutch prohibition mechanism. The Netherlands allows the District Court to prohibit legal persons, including political parties, which legally exist as non-state associations, ${ }^{130}$ under Article 2:20 of the Dutch Civil Code (DCC) when their activities are "contrary to public order."131 The Dutch government's explanation of Article 2:20 emphasizes that "only actions that infringe on the generally accepted foundations of [the Netherlands'] legal system can justify the prohibition of an association," and claims that the two key ideals behind these foundations are "the freedom of others" and "human dignity." ${ }^{32}$ However, while this explanation refers to human dignity—an important component of a substantive democracy-it makes no reference to the underlying political framework. ${ }^{133}$ Instead, it focuses on the importance of preventing both illegal discrimination and the incitement of hate. ${ }^{134}$ The last instance of the Dutch judiciary banning a political party exemplifies this. In 1998, the Centre Party '86 (CP'86) was dissolved due to its racist and xenophobic rhetoric. ${ }^{135}$ The question of whether it was anti-democratic was not discussed. ${ }^{136}$

A further consideration is the fact that Article 2:20 also exists to dissolve criminal organizations, which broadens the application and scope of the Dutch protected object. ${ }^{137}$ For example, Martijnwhich, notably, was not a political party — was dissolved by the Dutch Supreme Court in 2014 for advocating for the normalization and legalization of sexual relationships between adults and children. ${ }^{138}$

\footnotetext{
${ }^{126}$ In Refah, the opinion poll noting the expected growth of the Welfare Party was an important consideration for the ECtHR. While these polls were as acknowledged as uncertain, whether or not the ECtHR would have upheld the ban if that growth had not been predicted remains an open question.

${ }^{127}$ Kommers, supra note 6, at 566.

${ }^{128}$ NPD II at para. 535.

${ }^{129}$ Notably, the definition used under the ECHR is largely comparable to the underlying norm used by the BVerfG.

${ }^{130}$ Leenknegt, supra note 114 , at 713 .

${ }^{131}$ Art. 2:20 (DCC) BW (Netherlands).

${ }^{132}$ Molier, supra note 60, at 105 (quoting HR 1984/85 17, 476, 5 (Geljin Molier trans.) (Dutch Parliamentary Proceedings II) at 3).

${ }^{133} I d$.

${ }^{134} I d$. Note that equality and anti-discrimination are constitutionalized in Article 1 of the Dutch Constitution.

${ }^{135} \mathrm{Id}$. at 109 .

${ }^{136} \mathrm{Id}$.

${ }^{137}$ Leenknegt, supra note 115 .

${ }^{138} \mathrm{Id}$. at 718 .
} 
However, while the treatment of sexual relationships between adults and children has profound implications for the moral fabric of the Netherlands, it has no meaningful implications for the function of democracy. Nonetheless, this judicial finding informs the content of "public order," and therefore has implications - subtle as they may end up being in practice - for how party prohibition operates in the Netherlands. The prohibition of other criminal organizations under Article 2:20 - such as outlaw motorcycle gangs, which Leenknegt notes as a relevant threat ${ }^{139}$-would have similar implications if enacted, further expanding the scope of the Dutch protected object. Of course, the Dutch judiciary could develop different understandings of "public order" as it relates to political parties and as it relates to non-political criminal organizations, insulating the interpretation of the object as it applies to antidemocratic parties from how it is interpreted otherwise-similar to how it has suggested applying the imminence criterion to political parties but not necessarily to other associations. ${ }^{140}$ However, artificial distinctions such as these can be difficult to maintain in practice, especially when applied to a constitutional norm.

Due to this relative malleability of "public order," if the potentiality criterion were to be applied to Article 2:20 of the DCC, then the institutional pressure it imposes would be placed not only on organizations that seek to undermine democracy, but also on organizations that may support democracy but whose policies or behaviors might otherwise run contrary to the generally accepted foundations of the Netherlands. This lower threshold would suffocate their rights to association and enliven the risk-averse behavior, even in cases where there was no threat to democracy itselfremembering that this threat, crucially, is the primary justification for a militant democracy. The German Basic Law, by having a comparatively narrow protected object, constrains this effect to political parties that threaten to undermine democracy itself, ensuring that there remains a meaningful connection between the impairment imposed and the overall goal of militant democracy.

Further, the behaviorally suppressant effect of potentiality may not only be tied to the ideological platforms pushed by the parties. It may also have an institutional effect on the party's structure, as membership numbers-a key factor in the potentiality analysis-are crucial to the power of a political party. ${ }^{141}$ Judith Wise, in her analysis of the Free German Workers Party-a misnomer, as the organization was only an association at the time-explores how anti-democratic parties often seek political advantages by claiming to be smaller or larger than they are. ${ }^{142}$ On the one hand, an organization can create a façade of legitimacy by pretending to be larger than it is. ${ }^{143}$ On the other hand, it can choose to appear smaller and more fragmented to mask the threat that it presents. ${ }^{144}$ Notably, the BVerfG stressed the importance of the party's "current circumstances,"

\footnotetext{
${ }^{139} \mathrm{Id}$.

${ }^{140}$ Article 2:20 does not prescribe a threat mechanism. Nor does it rely on only one. The most recent ruling banning an association—the Martijn case in 2014 (HR 18 April 2014, AB 2014/348)—explicitly referred to Refah and adopted the concept of necessity from the ECtHR but did not elaborate on the question of timing. However, Martijn was not a political party-it was an association that advocated for the legalization of sexual relationships between adults and minors. Further, the dissolution of CP' 86 preceded Refah and was decided solely on the substantive criterion "contrary to public order". Accordingly, the Dutch courts have not yet had the opportunity to apply, or disregard, Refah on the question of political exclusion. However, the Dutch government produced the Memorandum on Antidemocratic Groupings in 2015, which concluded that a ban is justifiable if "in the case of political parties . . . it has been shown to be likely for the danger of a policy to realize such [anti-democratic goals] to be sufficiently imminent". Molier, supra note 60, at 110 (quoting Dutch Parliamentary Proceedings II (House of Representatives) 2014/15, 29,754, 226 (Gelijn Molier, trans.), at 19). Further, Articles 93 and 94 of the Dutch Constitution mandate compliance with any treaty that binds the Netherlands, which includes the ECHR. Consequently, it is highly likely that the Court would adopt the government's use of the Refah test by applying the ECtHR's threat criterion.

${ }^{141}$ Judith Wise, Dissent and the Militant Democracy: The German Constitution and the Banning of the Free German Workers Party, 5 U. Chi. L. Sch. Roundtable 301 (1998).

${ }^{142} I d$.
${ }^{143} I d$.
${ }^{144} I d$.
} 
"societal impact," and "public representation" to its analysis of potentiality. ${ }^{145}$ Accordingly, the strategy of overstating size and influence is now riskier for anti-democratic groups, as while these representations would not satisfy the requirements of imminence, they may construct an image capable of invoking potentiality, as an increase in the party's size, perceived or actual, has a bearing on the above three variables. Consequently, the safer strategy for an anti-democratic party in this environment is to remain-or appear to remain — small, robbing it of the opportunity to secure legitimacy by overstating its size. This further relegates anti-democratic parties to the fringe of politics, limiting their options to mere survival or a rebranding. ${ }^{146}$ Failing to do either could result in dissolution, and thus a total loss of political capital and legitimacy.

These conclusions on the suppressant effects of potentially are not necessarily rebutted by the fact that the NPD has operated despite the existence of Article 21(2) since 1964, surviving multiple ban attempts with no observable change in behavior. Prior attempts to ban the NPD-including the first hearing by the BVerfG on the matter-failed due to either a lack of political inertia or, ${ }^{147}$ in the case of the previous ban attempt in 2003, the evidence being contaminated by the presence of state informants in the upper echelons of the party. ${ }^{148}$ Accordingly, the anti-constitutionality of the NPD had not been affirmed by the BVerfG until NPD II. Since then, it has limped along at the same rough level of influence, secure in the knowledge that its current status is insufficiently powerful to merit a ban. The party to consider now is the Alternative for Germany (AfD) established in 2013, it quickly devolved into ultra-nationalistic, hard-right populism, cannibalizing what may have otherwise been NPD's base demographic. Notably, the AfD has repeatedly distanced itself from the NPD and taken great pains to claim it remains within the bounds of the Basic Law. Unfortunately, an empirical case study of how the AfD's political behavior may have changed in the aftermath of NPD II is beyond the scope of this article. However, the recent classification of one of its factions, Der Flügel, as against the free democratic basic order by the German Federal Office for the Protection of the Constitution in March 2020 makes it an appropriate time to consider such research, ${ }^{149}$ especially because the AfD has since made efforts to distance itself from it.

\section{The Basic Law and the BVerfG's Institutional Identity}

The justification of potentiality requires two more concerns to be addressed. First, the benefits of potentiality should not be outmatched by the additional impairment on the rights to association and participation. If they are, the use of potentiality instead of imminence represents a net loss for democracy. The second concern, which affects the first, is whether political forces can amplify the impairment caused by potentiality by applying pressure to the court making the decision.

Majoritarian forces can be motivated to remove anti-democratic parties for a host of reasons. Idealistically, it could be out of a desire to improve the polity. ${ }^{150}$ Cynically, it could be to remove potential competition in the political economy. ${ }^{151}$ It could even be sought as a pretext for coercive action against the organization in question. ${ }^{152}$ This is not to claim that the majority in a

\footnotetext{
${ }^{145} \mathrm{NPD} I I$ at para. 587.

${ }^{146}$ Schuldt, supra note 76 , at 841 .

${ }^{147} I d$. at 836.

${ }^{148}$ See Capoccia, supra note 8, at 212. See also Melissa Eddy, German Court Rejects Effort to Ban Neo-Nazi Party, THE New York Times (Jan. 17, 2017), https://www.nytimes.com/2017/01/17/world/europe/german-court-far-right.html.

${ }^{149}$ Philip Oltermann, German spy agency puts part of far-right AfD under surveillance, THE GUARDIAN (Mar. 13, 2020), https://www.theguardian.com/world/2020/mar/12/german-intelligence-agency-puts-part-of-far-right-afd-under-surveillance.

${ }^{150}$ David Fontana \& Aziz Z Huq, Institutional Loyalties in Constitutional Law, 85 U. CHI. L. Rev. 1, 22-24 (2018).

${ }^{151}$ Joseph Schumpeter, CAPITALiSM, Socialism AND DemOCRACY 241-51 (1943); Bourne, supra note 63, at 41-42. See Tyulkina, supra note 75 , at 69 , noting that any member of a party declared to be unconstitutional will lose their Bundestag seat automatically.

${ }^{152}$ For example, the ban of the KDP was used as a trigger for a "severe crackdown on subversive activities throughout the Federal Republic", see Kommers, supra note 6, at 229.
} 
democratic government is presumptively corrupt. Instead, it is to reinforce the political nature of democratic exclusion. Because an application under Article 21(2) of the German Basic Law can only be brought by the Bundestag, ${ }^{153}$ the Bundesrat, ${ }^{154}$ or the Federal Government, any attempt to ban a party is inherently political. ${ }^{155}$ Further, because the BVerfG's approach does not require the party to be a specific threat, ${ }^{156}$ the possibility of potentiality being misapplied is increased, as an application can be plausibly brought against a broader range of anti-democratic actors. Accordingly, the question is whether the BVerfG is vulnerable to majoritarian pressure.

This possibility is not unfounded. The BVerfG has shown sensitivity to political pressure in the past. At the time of the SRP and KDP bans, it had comparatively little legitimacy. ${ }^{157}$ Its independence remained tenuous, with the government entertaining reforms that would grant it greater influence over nominating its judges. ${ }^{158}$ The KDP Case is demonstrative. The application to ban the KDP was filed in November 1951, the same month in which the government sought to ban the SRP. ${ }^{159}$ While the SRP Case was decided in 1952, the KDP Case was not resolved until 1956. The delay was due to several of the BVerfG's judges believing the action against the KDP to be premature, especially because the KDP's electoral support was declining. ${ }^{160}$ In response to this delay, however, the government began actively exploring how to curb the BVerfG by restructuring its jurisdiction. ${ }^{161}$ It was only in 1956, when the BVerfG became convinced that the government would not relent, that it resolved the application. ${ }^{162}$ Notably, this kind of interference was not explicitly barred by the German Basic Law at the time. Article 115g, which provides that the functions of the BVerfG and its judges "must not be impaired," was not introduced until 1968. ${ }^{163}$ Accordingly, while it was implicitly understood that the judiciary should remain independent in accordance with the separation of powers doctrine, this norm of non-interference had not been codified in the Basic Law.

However, these vulnerabilities of the BVerfG eroded over time. The design of the BVerfG explicitly seeks to minimize its vulnerability to political influence. ${ }^{164}$ The Basic Law guarantees it personal and material independence. ${ }^{165}$ It holds a jurisdictional monopoly over the question of political exclusion under Article 21(2) of the German Basic Law. ${ }^{166}$ Today, the BVerfG is considered to be at the epicenter of Germany's constitutional democracy. ${ }^{167}$ It is positioned outside the regular court system, ${ }^{168}$ remains relatively insulated from politics, ${ }^{169}$ and has a reputation as one of the most independent and powerful constitutional tribunals in the world. ${ }^{170}$

\footnotetext{
${ }^{153}$ The Bundestag is the German federal parliament.

${ }^{154}$ The Bundesrat represents the sixteen federated states of Germany.

${ }^{155}$ Act on the Federal Constitutional Court, Aug. 11, 1993, BundesgeSETZBLAtT [BGBL] I at 1473, $§ 13(2), 43(1)$ (Ger.) (Iyamide Mahdi and Ute Reusch, trans.).

${ }^{156}$ NPD II at para. 522.

${ }^{157}$ Niels Petersen, Balancing and Judicial Self-Empowerment: A Case Study on the Rise of Balancing in the Jurisprudence of the German Federal Constitutional Court, 4 Glob. Constitutionalism 49, 70 (2015).

${ }^{158} I d$. at 70 (citing Heinz Laufer, Verfassungsgerichtsbarkeit Und POLITISCHER Prozeß 167-69 (1968)).

${ }^{159}$ Justin Collings, Democracy's Guardians: A History of the German Federal Constitutional Court 1951-2001 38-39 (2015).

${ }^{160} I d$. at 40-41. See also Kommers, supra note 6, at 227.

${ }^{161} I d$. at 43. See also Donald Kommers, Judicial Politics in West Germany (1976), in Comparative ConstitutionaL LAW 541 (Vicki C Jackson and Mark Tushnet eds., 2006).

${ }^{162}$ Kommers, supra note 6, at 227-28.

${ }^{163} I d$. at 19.

${ }^{164}$ Jutta Limbach, The Concept of the Supremacy of the Constitution, 64 MOD. L. REv. 1, 7 (2001).

${ }^{165}$ See Id. at 9-10. See also Grundgesetz [GG] [Basic Law], art. 97.

${ }^{166}$ Issacharoff, supra note 59, at 1455.

${ }^{167}$ Kommers, supra note 6, at 63 .

${ }^{168}$ Heun, supra note 111 , at 166.

${ }^{169}$ CURRIE, supra note 79 , at 27.

${ }^{170}$ Kommers, supra note 6, at 64; Heun, supra note 111, at 170; Collings, supra note 159, at xxix (citing Matthias Jestaedt, Phänomen Bundesverfassungsgericht. Was das Gericht $z$ u dem macht, was es ist, in Matthias Jestaedt et al., DAS ENTGRENZTE GERICHT: EINE KRITISCHE BILANZ NACH SECHZIG JAHREN BundESVERFASSUNGSGERICHT 149 (2011).).
} 
Crucially, its public favor outstrips most other institutions in Germany, ${ }^{171}$ granting it a wealth of diffuse support with which to make counter-majoritarian decisions. In May 2014, when Germany celebrated the sixty-fifth anniversary of the Basic Law, a survey showed 86 percent of Germans trusted the BVerfG, with only five percent seeing it as too powerful. ${ }^{172}$ When compared to some neighboring constitutional courts, such as those in Poland, ${ }^{173}$ the BVerfG is comfortably one of the most powerful.

The obvious benefit of this status is that it provides material protection against direct court curbing. However, neo-institutionalism also provides insight into the behavioral implications of these developments. People maintain "repertoire[s] of roles and identities" that prescribe "appropriate behavior in situations for which they are relevant." ${ }^{74}$ Appropriate action is not based strictly on traditional understandings of rationality, but also on mutual, "tacit understandings of what is true, reasonable, natural, right, and good." 175 Crucially, the BVerfG has a tightly defined identity. Its sole purpose is judicial review. ${ }^{176}$ It identifies as the guardian of the Basic Law, ${ }^{177}$ and regards itself as a constitutional organ with the same importance as the Bundestag, Bundesrat, and the Federal President. ${ }^{178}$ Its statements in earlier prohibition cases reflect this self-perception. In the KDP Case, the BVerfG claimed that Article 21(2) of the German Basic Law offered greater protection against the suppression of legitimate oppositions than other, similar mechanisms because it gave exclusive authority to an independent constitutional court. ${ }^{179}$ Consequently, its status as an independent and equal body is not simply structural. It is normatively internalized to a high degree, and this identity as an autonomous protector of the German constitution influences the BVerfG's reasoning and imposes strict norms of appropriateness. ${ }^{180}$ This, combined with the material protections afforded to the BVerfG, heavily mitigates the possibility of majoritarian pressure affecting its judgment. Naturally, these considerations are not absolute bars to political influence. Complete insulation is arguably impossible, and a judge's underlying sentiment about policy remains capable of motivating her behavior even when it conflicts with her institutional interests. ${ }^{181}$ However, based on the above factors, it is highly unlikely that the application of potentiality would be amplified by political pressure in the German institutional environment.

Accordingly, the constitutional protections afforded to political parties in Germany are particularly difficult to erode. In Germany, parties are "more than mere political-sociological [organizations]." 182 They are "constitutional institutions." 183 This is not the case everywhere. For example, the Netherlands, beyond a governmental memorandum favoring the use of the imminence criterion for party prohibitions, ${ }^{184}$ has not formally made the distinction between

\footnotetext{
${ }^{171}$ See Kommers, supra note 6, at 65 . See also Collings, supra note 159 , at $\mathrm{xxx}$.

${ }^{172}$ Collings, supra note 159 , at $\mathrm{xxxi}$.

${ }^{173}$ The democratic regression of Poland is an example of how an elected populist party can dismantle relatively weak constitutional courts through extensive curbing. The Polish Law and Justice Party was elected in 2015. It rapidly proceeded to paralyze and then stack Poland's Constitutional Tribunal. It then proceeded to capture Poland's Supreme Court by taking control of the National Council of the Judiciary, which is responsible for appointing judges, and leveraging pressure through that body. While a full discussion of Poland's constitutional decline is beyond the scope of this article, Wojciech Sadurski has written extensively on the subject, see Wojciech Sadurski, How Democracy Dies (in Poland): A Case Study of Anti-Constitutional Populist Backsliding, SYD. L. SCH. RsCH. PAPER No. 18/01 (2018).

${ }^{174}$ March \& Olsen, supra note 14 , at 2.

${ }^{175} \mathrm{Id}$. at 2 .

${ }^{176}$ Kommers, supra note 6 , at 3 .

${ }^{177}$ See Heun, supra note 111, at 167-68 (citing 1 BVerfGE 184, 195). See also Collings, supra note 159, at xxxv.

${ }^{178} I d$. at 168 .

${ }^{179}$ CURrIE, supra note 79, at 219 (citing the KDP Case).

${ }^{180}$ See March \& Olsen, supra note 13.

${ }^{181}$ Fontana \& Huq, supra note 150, at 22-23.

${ }^{182}$ SRP Case, in Kommers, supra note 6, at 202.

${ }^{183} \mathrm{Id}$.

${ }^{184}$ Molier, supra note 61 , at 110 .
} 
political parties and associations. The Dutch Constitution offers no protection to political parties, ${ }^{185}$ and while the Dutch Electoral Act separately regulates associations that participate in elections, it does not afford them any additional protection. ${ }^{186}$ The entrenchment of the importance of political parties in the German Basic Law is crucial to empowering the BVerfG, as the custodian of that Basic Law, to resist majoritarian pressure. ${ }^{187}$

This touches on another crucial issue with potentiality, which is its malleability. Linguistically, its lower threshold is bounded by whether the party is "entirely unlikely" to succeed in its goals. However, democracy necessarily assumes the possibility of a minority becoming a majority. ${ }^{188}$ The issue is that the phrase "entirely unlikely" lacks a determinative linguistic boundary, and the sole reference point available is NPD II itself. However, it is not inconceivable that an organization with hundreds of local representatives and a Member in the European Parliament could, at some point in the future, succeed politically, so the interpretation of potentiality as requiring a greater degree of influence is arguably a pragmatic one, and that interpretation could easily shift if more cases were brought before the court. This scope for a shifting interpretation is what remains exposed to political influences. Fortunately, in the case of the BVerfG, its status as the guardian of the German Basic Law, combined with the constitutional importance of political parties, provides a countervailing bias against interpreting potentiality too broadly.

Of course, it could be argued that the ECtHR's approach also has semantically vague boundaries, with the same risks of interpretation and politicization. However, the imminence criterion from Refah presupposes a significant degree of restraint by requiring "plausible evidence" of an "imminent threat," with dissolution being justified "only in the most serious cases"; these constraints immediately reduce the degree of prospective analysis required by the court. Potentiality, by comparison, does not presuppose this degree of restraint. Instead, it speaks of more distant and hypothetical possibilities, relying on a loose concept of unlikelihood to limit its scope. Under an approach like this, restraint needs to come from the institutional environment to render the criterion democratically viable. Germany's democracy is structured to provide such restraints under its Basic Law. A democracy without those structures, by comparison, implements potentiality at the risk of it expanding beyond its original purpose. Accordingly, for states lacking the German institutional structure, imminence is the more democratically viable option.

Fortunately, there is currently little evidence to suggest that later party bans under the Refah threshold result in any democratic backlash. Tim Bale's analysis of political exclusion in Turkey, Belgium, and Spain, all of which rely on the ECtHR's approach, ${ }^{189}$ found that none of the party bans in those states produced any negative effects. ${ }^{190}$ This does not mean that the Refah approach is necessarily ideal in every circumstance. However, it does question the necessity of potentiality in the broader European context. If Bale's conclusions can be generalized to Germany, then the only meaningful differences between the two criteria would be the amount of pressure imposed on antidemocrats, the degree to which their right to association is respected, and the length of time for

\footnotetext{
${ }^{185}$ Grondwet voor het Koninkrijk der Nederlanden [GW] [Constitution] (Translation Department of the Minister of Foreign Affairs of the Netherlands, trans.).

${ }^{186}$ See Leenknegt, supra note 115, at 728. See also Elections Act, Sep. 28, 1989 (Neth.).

${ }^{187}$ One element worth considering, however, is the potential influence of which institution brings the action to prohibit a party. In Germany, the action is brought by the Bundesrat or Bundestag. In the Netherlands, by comparison, the action is brought by the Public Prosecution Service, which, while overseen by the Minister of Security and Justice, ultimately operates as a sub-branch of the judiciary. See Maria IJZermans \& AnNie De Roo, Dispute Resolution Inside And Outside the Courts in Understanding Dutch Law 76-77 (Sanne Taekema et al. eds., 2d ed. 2011). This somewhat insulates the decision to bring the action from the same kind of majoritarian pressure that a claim before the BVerfG is expected to have.

${ }^{188}$ Frankenberg, supra note 56, at 259.

${ }^{189}$ See Tim Bale, Are Bans on Political Parties Bound to Turn Out Badly? A Comparative Investigation of Three "Intolerant" Democracies: Turkey, Spain, and Belgium, 5 Comp. Eur. Polit. 141 (2007).

${ }^{190} I d$.
} 
which they are exposed to the acculturative influence of the majority. ${ }^{191}$ Nevertheless, risk assessment is a deeply context-specific exercise. Bale's assessment of these other European states, while valuable, is not determinative in Germany. Accordingly, because Germany's institutional structure mitigates some of the dangers of relying on a lower threshold, the use of potentiality in Germany is defensible until the risks of a later ban in its environment are studied. As more data is collected, the interpretation of Article 21(2) should be reappraised. If it is found that there are no dangers associated with instead employing the imminence criterion, then a further shift towards the ECtHR's jurisprudence is ideal.

\section{E. Defending Democracy}

This preference for imminence does not completely dissolve the concerns about the vulnerabilities of democracy. After all, it could be argued that, as faith in democracy declines, ${ }^{192}$ the use of a more restrained approach may risk too much. Because one role of the judge in a democracy is to protect democracy itself, ${ }^{193}$ the possibility of empowering that judge to ban a party sooner is tempting.

However, there are other militant mechanisms for constraining anti-democratic actors and signaling the boundaries of acceptable political activity. Limiting party funding is one of the most common means of regulating party behavior, ${ }^{194}$ and this can both weaken the targeted party, by reducing its funds for advertising or activism, and signal its undesirable status within the political arena. Prohibitions on speech can construct the acceptable language and vocabulary of democratic politics, minimizing the scope for hateful or discriminatory platforms to secure legitimacy. ${ }^{195}$ In states which grant television or radio advertisement times to political parties, this access can be revoked for parties that push anti-constitutional ideas. ${ }^{196}$ There is even the possibility of allowing an anti-democratic party to exist, but denying its right to be included in the electoral ballot: Israel leaves space for anti-democratic political parties to organize while denying those parties representation in the Knesset. ${ }^{197}$

As such, the framing of what constitutes valid political activity can be done with less coercive mechanisms that suppress anti-democratic behavior while still allowing such parties to exist. An imminence threshold, if implemented alongside these mechanisms, can act as a safeguard, empowering the judiciary to act as a veto player against any anti-democratic party that, despite these other measures, manages to accrue enough support to be deemed an imminent threat.

Of course, all of this assumes the pre-existence of anti-democratic players in the game. The defense of democracy should not be exported entirely to the judiciary. Democratic institutions also need to be designed to address the sources of the threat. Ultimately, anti-democratic sentiment is not an idiopathic phenomenon. It is the product of social, economic, and political conditions. As the world changes, the opportunities that people expected can evaporate, and failing to protect and support the most vulnerable in a democratic society can leave them motivated to seek alternatives.

Core parts of the democratic project, alongside meaningful participation and representation, are human dignity and a sense of collective belonging, and implementing policy that strives for

\footnotetext{
${ }^{191}$ This assessment leaves aside the possibility of there being a greater risk of error under potentiality due to its more speculative nature. More research into how judges assess risk is required before this can be regarded as a potential factor.

${ }^{192}$ See Kim Scheppele, Autocratic Legalism, 85 U. CHI. L. REv. 545, 546 (2018) (noting that every Freedom House democracy indicator has declined since 2006, and that 105 countries suffered net declines in democracy indicators from 2006 to 2016) (citing Arch Puddington, Breaking Down Democracy: Goals, Strategies, and Methods of Modern AUTHORITARIANS 3-5 (2017)).

${ }^{193}$ Barak, supra note 36 , at 20.

${ }^{194}$ See Grundgesetz [GG] [Basic Law] art. 21(3). See also Bourne, supra note 62, at 37.

${ }^{195}$ Issacharoff, supra note 59, at 1423-29.

${ }^{196} \mathrm{Id}$. at 1447 (citing the BVerfG's decision in 47 BVerfGE 198).

${ }^{197} I d$. at $1448-49$.
} 
and maximizes these qualities is a stronger defense to democracy than any prohibition mechanism. Civic education, the reinforcement of local government, the promotion of pluralism, the erosion of barriers to participation, stronger social programs, economic opportunity, and a dedication to substantive equality - to name a few-are crucial to a healthy democracy, and there is always scope for progress. After all, anti-democratic sentiment is not just a problem to be solved. It is the product of problems that have been ignored. Political exclusion is an important last resort, but it is ill-equipped to be a complete remedy. To protect democracy, nurture it.

\section{F. Conclusion}

The effects of the various thresholds for political exclusion depend on the institutional environments in which they are employed. This article, by drawing on comparative constitutional law, behavioralism, and neo-institutionalism, explores three different criteria for political exclusion. Critically, the new potentiality criterion employed by the BVerfG has significant advantages over Germany's prior substantive test. Further, the use of potentiality rather than imminence in Germany is defensible. While it does result in a greater impairment on the legitimate rights of anti-democrats than the ECtHR's approach, the additional protective pressure that it provides, combined with the political insulation of the BVerfG, means that this additional impairment is likely commensurate to the benefits of potentiality. However, this new criterion should not be applied universally. The use of potentiality for a less tailored exclusion mechanism, in an environment with fewer judicial and party protections, would introduce significant democratic risks. Consequently, the ECtHR's approach to political exclusion should be retained until further research and reform is conducted.

Certain gaps in the argument should be acknowledged. First, several methodological assumptions were made. While the insights from neo-institutionalism and behavioralism are empirically ratified, they still refer only to biases in behavior. Accordingly, they cannot be regarded as deterministic. Their value is in how they highlight risk, which, given the nature of the research question, is highly relevant to the analysis. Second, the scope of this article limits the comparative analysis. The choice of countries was restricted to those that publish their legal materials in English, and the length of analysis meant that only one major case study was feasible. A larger-N study would provide greater insight. Third, this article does not account for confounding factors such as cultural attitudes and the personality traits of individual judicial and governmental officials. Accordingly, this article is limited to a degree of generality.

However, these limitations do not nullify the article's conclusions. The patterns of democratic behavior are simply the starting point for assessing how to protect democracy. Political exclusion is one of many tools available for combatting anti-democratic sentiment. Developing a prohibition mechanism tailored to its institutional environment requires research and refinement. In the interim, democracy still has other mechanisms to protect itself. Ultimately, the growth of antidemocratic sentiment requires more an exclusion mechanism to cure.

Cite this article: Hogan J (2022). Analyzing The Risk Thresholds For Banning Political Parties After NPD II. German Law Journal 23, 97-116. https://doi.org/10.1017/glj.2022.1 